\title{
DEPOPULATION AS AN OPPORTUNITY FOR, NOT A THREAT TO CITIES AND REGIONS: A PARADIGM CHANGE
}

\author{
Wojciech Janicki \\ Faculty of Earth Sciences and Spatial Management \\ University of Maria Curie-Sklodowska \\ Al. Krasnicka 2 cd, 20-718 Lublin: Poland \\ wojciech.janicki@umcs.pl
}

\begin{abstract}
The process of population decline in highly developed countries is commonly perceived as a problem, particularly in some regions of these countries. Population growth is likewise seen as a daunting challenge. This indirectly leads to the conceptually faulty conclusion that the one and only balanced and safe population size is the current one. In reality, negative population growth on both national and regional levels also has its advantages - which do not typically garner much interest or consideration, obscured by the unsubstantiated argument that depopulation is mostly damaging to the well-being of the nation. Regardless of the pros and cons of depopulation, the fact that the process is underway is undisputable. Depopulation is generally accompanied by accelerated rates of aging in a given population. Given the dearth of effective tools to reverse these trends, it is wiser to cease all attempts to reverse the irreversible and instead focus on preparing the organizational structures of states and regions for the economic and social ramifications of depopulation.
\end{abstract}

Keywords: depopulation, population policy, demographic optimum, emigration, natural decrease.

\section{Introduction}

Changes in the population of a country typically provoke concern, irrespective of whether a given change involves decline or incremental growth. This observation holds irrespective of whether the trend results from natural population growth or from migration, because changes of this kind always entail new challenges for the administrative apparatus of the country. These challenges can be manifold, depending on the country's level of economic development and the trend of demographic changes.

High rate of natural growth, which is characteristic of less developed countries, may lead to ever greater difficulties in feeding their citizens, in addition to furthering the risk of urban overcrowding. It can impede the state from ensuring the citizens access to basic technical infrastructure, from fighting unemployment or from developing the education system. Negative natural growth, which is a reality in a large part of the world's most developed countries and the former Soviet bloc alike, partly due to increased mortality rates resulting from aging societies, generates fears related to the growing costs of insurance and, in more dramatic forecasts, the eventual breakdown of pension systems and 
a general slowdown in economic growth. In the political realm, the position of the country on the international stage may be described as having been undermined, as reflected to some extent in its population. On its part, the population decline itself is understood as worrying and detrimental to the country. A high positive migration rate stokes fears that the immigrants will create competition for the autochthons on the labor market, in addition to the inevitable clash of cultures and the tension that may result from it. Finally, high outmigration of native inhabitants may result in labor shortages, as well as in difficulties in assembling a quality work force, and in a breakdown of the pension system, which in many countries revolves around intergenerational money transfers. All the examples given here are commonly invoked by those who fear the ramifications of population change. A closer look at them, however, may reveal that many result from the destabilizing effect of changes on society's collective notion of security. They are not necessarily caused by a real and imminent threat created by the new demographic situation.

The aim of this paper is to take a critical look at the issue of population decline and to tackle the idea that this process is inherently a negative and damaging one. The paper has no ambition to create an exhausting analysis of depopulation of any given area but rather to point to shortages of not-wellargued but prevalent assumption that depopulation should be fought against with all accessible means as it is of highly devastating nature. The elaboration will employ multiple spatial dimensions with examples derived from both global and country levels, down to regional and city levels, as changes of population are visible at all these levels and generally they are perceived negatively. First, global scale will be examined against the background of former demographic forecasts and their then-expected disastrous effects, now easy to verify. Then exemplary threats to countries, regions and cities resulting from depopulation will be presented along with proposed counteractions. Finally, the commonly overlooked benefits of depopulation will be demonstrated.

\section{Depopulation as a threat - predictions and facts}

At the beginning of 1960s, the world population stood at about 3 billion people, and was growing rapidly. This gave rise to frequent and vocal concerns about the future of the Earth, our capacity to feed the world population and secure basic demand for resources, including energy. Though much ink was spilled on the topic in that and later periods, there were several highly influential publications that suggested the Earth was on a collision course to reaching peak capacity, overpopulation, and global economic catastrophe. Most notable among these are The Population Bomb (Ehrlich 1968), The Limits to Growth (Meadows et al. 1973), and the most recent The Population Explosion (Ehrlich \& Ehrlich 1991). One recurring prediction was that hundreds of millions of people would be dying of hunger by the end of 1970s. At the same time, before the end of the millennium, the supply of all basic non-renewable energy sources - including fuel - would dwindle. Similar publications were seen in later periods, including recently, which signals a need to rein in major decreases and increases in population size and draw practical conclusions on the effect humans have on the environment. Some of these are scientific in nature; others simply rehash and disseminate neo-Malthusian concepts, which generates increasing fear of overpopulation among readers who are not embedded in the scientific field (see Kunzig 2011).

Human use of essential resources and generation of pollutants has surpassed sustainable rates. Unless there are significant reductions in material and energy flows, the world faces an uncontrolled decline in per capita food output, energy use, and industrial production. (Meadows et al. 1992: 14). 
The neo-Malthusian thrust of the citation above leaves little room for interpretation - humanity should decrease its pressure on the natural environment if it purports to survive in the mid- to long-term. Easing the pressure is possible as long as we first decrease the average consumption of resources per capita or the population total.

As has already been discussed, population growth has for years been widely considered to be a serious problem. The indirect assertion brought forth by supporters of curbing population growth is that the only balanced and safe population size is the current one, whatever it may be. Depending on when this assertion is made, this target population size is larger or smaller. In the 1960s, the then-current population of 3-4 billion was seen as the norm. Fast-forwarding to the modern day, the current figure of about 7 billion does not cause alarm in itself, but its continued rise triggers uneasiness and anxiety. This reaction is valid on psychological grounds - we fear the unknown while what is familiar to us simply isn't perceived as a threat (Riemann 2005). What is more difficult to comprehend is why research and scientific analysis remain in agreement with those fears, beholden to fear of the unknown.

Paradoxically, the human race is afraid not only of the consequences of excessive growth, but also excessive decline, despite the fact that we have experienced a lower overall population before. Scientific articles, popular science, and journalists all speak in one voice: we are facing a looming demographic and economic catastrophe, to which we will have to own up as a result of population decline. Low birth rates and high outmigration are both pictured as deleterious. For instance, writing in a purportedly rigorous and serious Internet forum (forsal.pl), Żółciak (2012) states already in the headline that: The demographic bomb is ticking: 500 communes, 70 districts and two voivodeships [regions] will disappear. In the article itself, which refers to the predictions made by the Central Statistical Office of Poland, we find out that by 2035 there will be a considerable decline in the population of some voivodeships - 17\% in Lubelskie, 15\% in Świętokrzyskie, and 14\% in Łódzkie. There are also assorted warnings regarding the erosion of local budgets, problems in maintaining existing infrastructure, the specter of closing down of schools and withdrawing of investments, and the pauperization of large swathes of the country. The less-than-cheerful summary informs us that [...] instead of the vibrant, colorful city life, we will increasingly be treated to the sight of open-air museums, forgotten and forlorn.

\section{The consequences of depopulation and coping strategies}

In reality, population decline may also be beneficial to the region it affects, despite popular opinion and the widespread belief that a shrinking population has largely negative consequences (Burke 1997; Burke 1999; Bouvier 2011). The tacit assumption is that a slight increase in the population count would be beneficial to a country or region while a decline, however slight, leads directly to social and economic catastrophe. A number of scholars view this assumption as fundamentally false (e.g. Meyerson 2001). For instance, a drop in the human population, seen in the context of overpopulation in many parts of the world, may yield real benefits to the environment and will almost certainly entail smaller overall demand for resources. Grant (2001) offers several examples, including lower greenhouse gases emissions, lower emissions of gases that cause acid rain (sulfur dioxide and nitrogen oxides), lower overall pollution of rivers, and improvements in the conservation status of certain plants and animals that today are threatened with extinction. Economic problems may crop up in the transitional phase between the point where a society reaches a certain population count and 
the point where it reaches a record low. It is therefore all the more important to properly address the issue of a smooth transition between the two, instead of undertaking desperate efforts to halt the decline (Abernethy 2001).

Transitioning to a less populous society and achieving social and economic stability in the new paradigm raises the greatest doubts. However, it is possible. One of the most commonly highlighted problems is that of labor shortage, discernible in the demographic profiles of many developed countries, resulting from second demographic transition. It is estimated that the working-age population of the EU-15 will shrink by about 43 million (17\%) by 2050. In some countries this process will take place much faster than the average - in Italy, for example, it is likely to shrink by $39 \%$ (Ivanov 2005). According to a different estimate that assumes a stable and consistent migration trend for the next 50 years, in line with the early $21^{\text {th }}$-century migration dynamics, the workforce in $27 \mathrm{EU}$ countries will shrink by $12 \%$ by 2052 . Were it not for the influx of external migrants, the decline would reach $28 \%$ (65 million people) while the total population of the region in question would fall by about $16 \%$ (Bijak et al. 2005). This deficit can be reversed through efforts to make better use of the potential of the current workforce or by falling back on the unemployed, particularly those who are in the working age but do not have a job (Grant 2001; Prskawetz \& Fent 2004). Within the EU member states there are considerable labor force reserves of the unemployed and the passive workforce whose reasons for inactivity is neither age nor health, but rather national policies. This includes social and professional groups that are entitled to early retirement. Who exactly enjoys these rights differs by country; quite often it is law enforcement officers (soldiers, police officers, firemen), but also groups that operate high-risk machinery and regularly face threats to their health, life, and well-being (Saczuk 2005).

Another way to counter the expected labor shortage would be to raise the retirement age. At the end of the $20^{\text {th }}$ century, the most common retirement age in highly developed countries was 60 or 65 , often depending on gender. These rules were established at a time when average life expectancy in this part of the world hovered below 70 years. Given that in most of the countries in question, life expectancy has now surpassed 80 years, adjustments to the pension system seem to be not only justified, but even essential, regardless of society's endorsement (Meyerson 2001, see also Golini 2005; Saczuk 2005). It is also necessary to revamp pension systems in such a way that each worker accumulates his or her own contributions for his or her own retirement - as opposed to the all-too-popular common pool system to which the workers of today contribute so that the workers of yesterday may benefit from it (Golini 2000; Espenshade 2001).

On both a global and individual national level, predictions of population change suggest that using migrants from less developed countries to make up for labor shortages and restore a 'healthy' age structure of the workforce in highly developed countries is entirely unfeasible. In order to maintain the current demographic balance in Italy, one of the most rapidly aging states in the world, the country would have to accept 2.2 million immigrants per year. This would mean that, in 2050, there would be 194 million people living in Italy, of which 79\% would be immigrants and their children (Grant 2001, see also Replacement Migration... 2000). Cases like this one imply that the only realistic, feasible, and sensible solution is to create the conditions necessary to ensure functionality, development, and prosperity for a society and economy with a reduced population (Abernathy 2001; Espenshade 2001). It is futile to attempt to go back to a society with the same age structure as several decades ago, primarily due to changes in fertility and mortality rates, both of which are affected by the natural growth taking place also among immigrant groups (see White 2006). According to Bijak et al. (2005), rather than battling the natural order of things and fighting in vain to reverse the slow yet enduring process of aging, it is better to focus on introducing changes to the structure of social life that will 
constitute a precise response to inevitable demographic changes. Supporters of this view point out that immigration should be understood as part of the toolkit for implementing large-scale change, but that we should expect it to induce improvements on the social and economic level rather than act as pure demographic salvation.

\section{The benefits of depopulation}

One indirect illustration of the beneficial results that outmigration may have for the source countries is the fact that certain states have actively encouraged their citizens to migrate, both today and in the past. This has been the case in Poland in the interwar period, when the government not only endorsed migration, but also took active steps to stimulate it, even though it took care to keep its efforts inconspicuous. State-funded societies and associations organized and facilitated settlement in South America; emigrants were entitled to discounted train tickets; and they were often relieved of passport fees (Kicinger 2005). These are but a few examples of a large set of factors that vicariously propped up outmigration from Poland. The added value that could potentially be gained from a sizable group of expatriates was the prospect of Poland acquiring colonies on other continents; the 'migrant method' of shifting human resources to other parts of the world was considered to be relatively cheap and effective. As history would later show, this aim was not achieved. Elsewhere in Europe, emigration was actively promoted, for example in the Netherlands (Jackson 1986), while in the direct aftermath of World War II, it was a very common phenomenon across Europe, which was commonly seen as overpopulated (European Commission 2003). In the contemporary era, similar campaigns are wedged in countries such as Mexico or the Philippines (Abernethy 2001). Relatedly, the existence of serious internal problems or strife in a given country makes emigration seem like a viable remedy for social and economic issues, including unemployment (see Koryś 2003).

If outmigration countries as a category can reap certain benefits from a shrinking population, then the same applies to regions with negative net migration rates. On the local level, this may lead to lower population density, with the myriad consequences it entails. In urban areas, a declining population can yield e.g. shorter transit and commuting times - a change caused by a smaller concentration of vehicles on the road. It may have a positive effect on the environment (through reduced emissions and pollution levels) as well as on the population of the city. Shorter commuting times mean less stress, which means greater efficiency at work as well as attenuating the negative effect of stress on overall health (circulatory problems, mental disorders, suicidal tendencies etc.). Having fewer inhabitants also brings down the price of rentals for both apartments and commercial space. One example of a city in which a significant population decline brought major social benefits is Leipzig, Germany. Setting aside the historical peak of its population (more than 700,000 inhabitants in the 1930s), Leipzig went from a city of 550,000 on the eve of German reunification to fewer than 450,000 ten years later, which the citizens have deemed highly beneficial to various aspects of everyday life as well as overall standards of living (Janicki 2009).

As outlined above, changes in the population of a given country or region may have both negative and positive consequences. There is no universal, conclusive tally or diagnosis of these consequences for countries or regions, irrespective of what their migration balance is. The conditions that shape the situation of any given region are unique to each of them. In spite of this, in states with negative net migration, academic publications and public opinion remain convinced that emigration has predominantly negative consequences. At the same time, in states where net migration is positive, 
the same groups believe that it is immigration that is harmful to their society. In either case, someone is left dissatisfied.

Neither emigration to other countries nor internal migration to other regions of the same country should be viewed as failures on the road to development, but rather as natural components of the development strategy of regions that are less developed than others (Skeldon 2003). Similarly, the inflow of migrants from other countries or regions should be treated as one of the components of social and economic transformations taking place in the modern, increasingly globalized world - one where growing inequalities in living standards constitute strong push factors that stimulate outmigration (Castles 2006). In practice, migration policies that radically stem the flow of incoming or outbound migrants lead to legally registered migrants being replaced by illegal migrants rather than truly limiting the overall movement of people.

\section{Conclusion}

The declining population of highly developed countries or certain regions thereof is an undeniable fact. This phenomenon gains much attention and is popularly seen as a demographic threat. However, recommendations that form the foundation of social policies that are often formulated based on common approach to depopulation, will not let the expected goals to be achieved. Time and time again it has been empirically proven that reversing the demographic falling trend or the aging of our societies is impossible. Neither programs that aim to increase the fertility rate nor increasing the influx of migrants are able to compensate for the losses resulting from natural demographic changes in aging societies; a return to the social and age structures of the past is simply not possible. Political solutions implemented in several countries and intended to arouse birth rates with economic or social stimuli are badly oriented and will not gain the expected results.

As such, instead of focusing our efforts on counteracting trends that are irreversible by nature, we should tailor and prepare the organizational structure of our countries and societies for the economic and social consequences of ongoing and future demographic changes. We should rather search for answers to demographic problems on non-demographic grounds. This can involve making better use of the potential of the current workforce, lifting pensionary privileges and early retirement of certain social groups, increasing the general retirement age regardless of society's endorsement and inducing improvements of labor market of the country with the use of wisely managed migration policy. A change of paradigm therefore becomes absolutely necessary; continuously dodging and ignoring the problem is a road to nowhere.

\section{References}

Abernethy V.D., 2001. Comment on Bermingham's Summary of the U.N.'s Year 2000 Replacement Migration, Is it a Solution to Declining Population and Aging? Population and Environment: A Journal of Interdisciplinary Studies, Human Sciences Press, vol. 22, no. 4, pp. 365-375.

Bijak J., Kupiszewska D., Kupiszewski M., Saczuk K., 2005. Impact of international migration on population dynamics and labour force resources in Europe, Central European Forum for Migration Research Working Paper 1/2005. 
Bouvier L.F., 2001. Replacement Migration: Is it a Solution to Declining and Aging Populations? A Journal of Interdisciplinary Studies, Human Sciences Press, vol. 22, no. 4, pp. 377-381.

Burke B.M., 1997. Uncoupling growth from prosperity: The U.S. versus Japan, NPG Footnote, August. Burke B.M., 1999. Japan's future is brightened by 'demographic' decline, Seattle Times, Nov. 19, B5. Castles S., 2006., Guestworkers in Europe: A Resurrection? International Migration Review, vol. 40, no. 4, pp. 741-766. Center for Migration Studies of New York.

Ehrlich P.R., 1968. The population bomb, Simon \& Schuster.

Ehrlich P.R., Ehrlich A.H., 1991. The population explosion. Simon \& Schuster.

Espenshade T., 2001. "Replacement Migration" from the Perspective of Equilibrium Stationary Populations, Population and Environment: A Journal of Interdisciplinary Studies, Human Sciences Press, vol. 22, no. 4, pp. 383-389.

European Commission, 2003. Migration and social integration of migrants. Valorisation of research on migration and immigration funded under 4th and 5th European Framework Programmes of Research. Brussels.

Golini A., 2000. Demographic trends and population policies, Pergamon, Futures 33 (2001), pp. 27-41.

Golini A., 2005. Population Aging and Labour Market: Two Italian Surveys, XXV International Population Conference, Tours July 18-23, 2005, International Union for the Scientific Study of Population.

Grant L., 2001. "Replacement Migration": The UN Population Division on European Population Decline, Population and Environment: A Journal of Interdisciplinary Studies, Human Sciences Press, vol. 22, no. 4, pp. 391-399.

Ivanov S., 2005. Population trends, employment and labour migration in the European Union. XXV International Population Conference, Tours, July 18-23, 2005, International Union for the Scientific Study of Population.

Jackson J.A., 1986. Migration, London-New York: Longman.

Janicki W., 2009. Interviews with inhabitants of Leipzig conducted during research stay in Universität Leipzig, 22-28 November 2009, unpublished.

Kicinger A., 2005. Polityka emigracyjna II Rzeczpospolitej, Central European Forum for Migration Research Working Paper no. 4.

Koryś I., 2003. Migration trends in selected EU applicant countries: Poland, Central European Forum for Migration Research Working Paper 5/2003.

Kunzig R., 2011. 7 billion, National Geographic, Special Series, January 2011, http://ngm.nationalgeographic.com/2011/01/seven-billion/kunzig-text [6 November 2015].

Meadows D.H., Meadows D.L., Randers J. 1992. Beyond the Limits: Confronting Global Collapse, Envisioning a Sustainable Future, Vermount: Chelsea Green Publishing Company, White River Junction.

Meadows D.H., Meadows D.L., Randers J., Behrens W. W., 1972. The limits to growth, Universe Books. Meyerson F.A.B., 2001. Replacement Migration: A Questionable Tactic for Delaying the Inevitable Effects of Fertility Transition, Population and Environment: A Journal of Interdisciplinary Studies, vol. 22, no. 4, pp. 401-409.

Prskawetz A., Fent T., 2004. Workforce Ageing and Economic Productivity: The Role of Supply and Demand of Labour. An Application to Austria [typescript].

Replacement Migration: Is it A Solution to Declining and Ageing Populations? 2000. Population Division, United Nations.

Riemann F., 2005. Oblicza lęku. Wydawnictwo WAM. 
Saczuk K., 2005. A development and critique of the concept of replacement migration, Central European Forum for Migration Research Working Paper 4/2003.

Skeldon R., 2003. Interlinkages between internal and international migration and development in the Asian region, Bangkok: Economic and Social Commission for Asia and the Pacific.

White P., 2006. Migrant Populations Approaching Old Age: Prospects in Europe, Journal of Ethnic and Migration Studies, vol. 32, no. 8, pp. 1283-1300.

Żółciak T., 2012. Demograficzna bomba tyka. Zniknie 500 gmin, 70 powiatów idwa województwa, http:// forsal.pl/artykuly/619410,demograficzna_bomba_tyka_zniknie_500_gmin_70_powiatow_i_ dwa_wojewodztwa.html [6 November 2015].

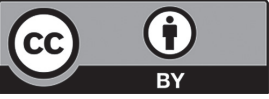




\section{INFORMATION FOR AUTHORS}

Manuscripts, in the English language, should be submitted to the Secretary of EUROPA XXI (Institute of Geography and Spatial Organization, Polish Academy of Sciences, Twarda 51/55 00-818 Warsaw, Poland; tkomorn@twarda.pan.pl).

The manuscripts should be arranged in the following order. First sheet: title, full name of author(s), affiliation, full postal address, e-mail address. Second sheet: abstract of no more than 100 words, key words (3-10) at the end of the abstract. Subsequent sheets: the main text of 5,000-8,000 words. The main text may be organized in sections under appropriate headings without numerals.

REFERENCES should be printed in alphabetical sequence at the end of the text. Examples:

\section{Articles from journals:}

Törnqvist G., 2004. Creativity in time and space. Geografiska Annaler. Series B. Human Geography, vol. 86 , no. 4, pp. 227-244.

Books:

Pacione M., 2001. Urban geography. A global perspective. London-New York: Routledge.

\section{Chapters from books:}

Haworth E.Y., Hurley M.A ., 1984. Comparison of the stelligeroid taxa of the centric diatom genus Cyclotella. [in:] M. Ricard (ed.), Proceedings of the 8th International Diatom Symposium, Paris-Koenigstein: Koeltz Scientific Books, pp. 43-58.

\section{Maps:}

Prest V.K., Grant D.G., Rampton V.N., 1968. Glacial Map of Canada. Map 1253A , 1:5000000, Ottawa: Geological Survey of Canada.

Unpublished documents (theses, 'grey literature'):

Kohno A ., Stubblefield A ., Rubin A.D., Wallach D.S., 2004. Analysis of an electronic voting systems. Johns Hopkins University Information Security, 23 pp. [typescript].

\section{Electronic and Internet documents or websites:}

CIT, 2012. NASA Jet Propulsion Laboratory. California Institute of Technology, http://www.jpl.nasa. gov/ [1 December 2011]. 
References should be indicated in the text by listing, in parenthesis, the author's name followed by the data of publication, e.g. (Haeberli 1975; Pacione 2001) or (Haworth \& Hurley 1984) or (Boudevillain et al. 2009) if there are more than two authors (Note: all the author s should be listed in the references).

FOOTNOTES and NOTES should be referred to by superscript letters.

ILLUSTRATIONS should be supplied in one of the following formats:

- photographs: JPG, TIFF, EPS or PSD,

- maps, figures and diagrams should be presented as vector files in $\mathrm{Al}$ (Adobe Illustrator) or one of the format mentioned above.

Please ensure that the resolution is not lower than $300 \mathrm{dpi}$ and the lines are a minimum of 0.3 points thick. Please also supply printouts of illustrations that are to be presented, in black and white or in colours, in relation to the required final appearance in print.

TABLES should be printed on separate sheets and numbered sequentially with Arabic numerals (e.g. Table 1). Each table should be provided with a clear descriptive caption at the top and informative column headings.

EQUATIONS and SYMBOLS used in mathematical formulae must be clearly explained. Axes on graphs should be described clearly. Units and abbreviations used by authors should conform to the International List.

MEASUREMENTS should be given in metric units.

ACCEPTED MANUSCRIPTS.

Articles accepted for publication in EUROPA XXI are not honoured financially. Authors of accepted articles will receive one copy of the journal free of charge.

Authors are responsible for indicating copyright as $w$ ell as permission from the copyright holder to reproduce any texts, tables or illustrations for which copyright exists. 


\section{ALL VOLUMES OF EUROPA XXI}

31 (2016) : Changing of spatial structure - production and transport issuses 30 (2016) : Territorial uncertainty as a challenge for regional policy in Europe 29 (2015) : The impact of climate on some sectorsof the economy in Poland and Bulgaria and their adaptation

28 (2015) : Road corridors in the natural,social and economic environment

27 (2014) : Territorial capital in practice - environmental and social issues

26 (2014) : The role of territorial capital in development polices

25 (2014) : Detecting Territorial Potentials and Challenges

24 (2013) : Transport accessibility at regional scale in Europe $\square$

23 (2013) : Services of General Interest in European Union

22 (2012) : Territorial development and cohesion in a multi-scalar perspective

21 (2010) : Environmental and infrastructural networks

20 (2010) : European Union: external and internal borders, interactions and networks

19 (2009) : European urban system: metropolization and networking

18 (2008) : Territorial dilemmas of socio-economic development in Europe

17 (2008) : New functions of rural and industrial space in Central and Eastern Europe

16 (2007) : Regional development in Central Europe - cohesion or competitiveness

15 (2006) : Regional periphery in Central and Eastern Europe

14 (2006) : Core and peripheral regions in Central and Eastern Europe

13 (2005) : New spatial relations in new Europe

12 (2005) : Central and Eastern Europe: changing spatial patterns of human activity

11 (2004) : Przestrzeń Europy. Przestrzeń Unii Europejskiej

10 (2003) : Society and environment. Towns and settlement in Europe

9 (2003) : Polska i Europa: kształtowanie przestrzeni wolności

8 (2003) : European space in the face of enlargement: the West to East European Trajectory project

7 (2002) : Slovakia and Poland: urban, social and demographic questions, relations between neighbours

6 (2001) : Integracja europejska - dylematy spójności i konwergencji regionalnej

5 (2000) : Przestrzeń ekologiczna Polski. Dekolektywizacja rolnictwa

i sytuacja zdrowotna w Europie Środkowej,

Wschodniej i Południowo-Wschodniej

4 (2000) : Powiązania handlowe Polski z Europą. Z debaty

o przyszłym kształcie zjednoczonej Europy

3 (1999) : Obszary szczególnej troski i nowych możliwości rozwoju na przykładzie Polski i Ukrainy

2 (1998) : Przestrzeń Europy Środkowej - przykłady transformacji

1 (1998) : Sieć komunikacyjna Polski w europejskich procesach integracyjnych 


\section{Environmental and demographic challenges for territorial development}

- Gábor Király, Márton Czirfusz, Bálint Koós, Gergely Tagai, Annamaria Uzzoli

Population projection for Hungary and its relation with climate change

- Katarzyna Dembicz, Oscar Barboza Lizano Environmental Cuba versus economic transformation

- Maria Bednarek-Szczepańska Rural tourism - "an apple of the eye" of rural policy in Poland

- Bożena Degórska, Marek Degórski Green infrastructure as a very important quality factor in urban areas - Warsaw case study

- Magdalena Szczepańska Family allotment gardens - the case of the Poznań agglomeration

- Wojciech Janicki Depopulation as an opportunity, not a threat to cities and regions: a paradigm change 